Governance of conservation area boundaries: agents and agencies in decision making

Luchuan Denga ${ }^{\mathrm{a}}$, Peter J. Larkham ${ }^{\mathrm{b}}$

${ }^{a}$ College of Urban and Environmental Sciences, Peking University, Beijing, China;

${ }^{b}$ School of Engineering and the Built Environment, Birmingham City University, Birmingham, UK

dengluchuan@pku.edu.cn; peter.larkham@bcu.ac.uk 


\title{
Governance of conservation area boundaries: agents and agencies in
}

\section{decision making}

\begin{abstract}
Conservation areas are a very common and popular planning tool, used by every UK local planning authority; but the basis on which related decisions are made often remains obscure, and so is the changing pattern of the conservation-related decision-making framework in British local governments.
\end{abstract} This paper provides an example of the changes in the decision-making framework for conservation area boundaries from the 1970s to the 2010s, using Cardiff, Wales as a case study. It sheds light on the governance documents of the local planning authority and reflects on the parts played by different types of planning-related agencies. Based on this example of the relationship between governance, decision-making, conservation and regeneration, this paper is able to examine the relationship between regeneration and conservation in a typical British cityies under the power of the New Right and New Labour.

Key words: conservation areas, boundaries, agents, decision-making, framework, regeneration.

\section{Introduction}

Urban conservation has been a major factor in managing UK cities for over half a century, since recognition of the problems of over-rapid growth and redevelopment led to legislation allowing the designation of conservation areas. Owing to the differing legal and administrative structures of the countries forming the United Kingdom, however, much of the research has focused on the effects in England 
(Pendlebury \& Strange, 2011; Historic Environment Forum, 2017). Conservation areas are a common, popular and comprehensible planning tool (Scrase, 1991), with their number growing from the first designation in 1967 to 'approximately 9866 ' in England, 600 in Scotland, 500 in Wales and 59 in Northern Ireland (Historic Environment Forum, 2018, p. 9; Scottish Executive, 2019; Cadw, 2017; Planning Portal, 2019). These are areas "of special architectural or historical interest, the character or appearance of which it is desirable to preserve or enhance" (1967 Civic Amenities Act, as amended). But popular does not mean unproblematic. In England, 517 designated areas ( $6 \%$ of the total) are considered 'at risk', $33 \%$ of conservation staff have been lost since 2007 (Historic Environment Forum, 2017) and the public campaigning organisation Civic Voice (2017) has sought to raise awareness of the value of conservation areas and their need for positive management. In this respect it is not only the designation of new areas that is of interest, but the ongoing evaluation and amendment of existing areas (see, for example, Historic Environment Forum, 2017, Figures 1 and 2); for conservation is and should be 'a dynamic force in shaping the planning of the contemporary city' (Pendlebury \& Strange, 2011, p.36). The precise placement of area boundaries, the reasons for these decisions, and the involvement of stakeholders and the way in which they interact and influence the decision-making processes are potentially problematic issues. Anomalies include designations often using street centrelines, yet people experience both sides of the street; some designated areas containing un-designated exclusions; and boundaries excluding features of undoubted interest (Larkham, 1997; Larkham \& Morton, 2011). 
These facts call for more careful investigation on the decision of conservation area boundaries.

In addition to the practical significance, the issue of conservation areas has generated long-lasting interest in the disciplines of urban morphology and heritage research. In urban morphology studies, researchers have been discussing the boundaries of conservation areas for decades, finding that in most cities examined there is a difference between conservation area boundaries and the boundaries of landscape units identified through academic study (e.g. Larkham, 1990; Bienstman, 2007; Whitehand, 2009). The difference has been ascribed to the lack of knowledge off the urban landscape; but a more plausible explanation has been identified, acknowledging the difference in the functions and the generation processes of the two kinds of boundaries. The conservation area, as a policy with spatial attributes, could be -innately different from the identification of landscape units, which do not involve the process of negotiation and compromise between agents (Larkham, 2000; Larkham \& Morton, 2011). More needsed to be done in exploring the nature of the decisionmaking process and the identification of agents as decision makers relating to conservation areas (Birkhamshaw \& Whitehand, 2012). Researchers in heritage conservation have also highlighted the important relationship between conservation areas and the system of governance (Pendlebury, 1999; Pendlebury \& Strange, 2011). The identification and conservation of 'heritage' could be seen as the selective utilization of built environment constructed by the societal, political and economic processes (Ashworth \& Graham, 2005; Pendlebury 2009; McDowell, 2016). In this 
way the boundaries of conservation areas stand out as ideal examples reflecting the fact that heritage is subjected to either the planning and governance system or the ideologies like consumerism or neoliberalism, as was put forward by Nasser (2003). To explore this interrelationship more fully, a case study on the boundary changes of conservation areas in Cardiff city centre has been undertaken. This could help not only ein the debate in urban morphology relating to conservation and urban change, but can also contribute to the detailed study of how the governance of conservation areas is constructed by social agents.

Generally speaking, scholars have realised the importance of connecting conservation areas (and the much wider issue of heritage) to the governance of boundary problems at the scale of cities (or regions), as the conservation of the historical environment is deeply embedded into the management of place and the decision-making framework of different types of agents (Pendlebury, 2009; Su, 2010). Although not dealing in detail with the changes made by agents to the boundaries of conservation areas, the ways in which agents of urban governance link to the conservation issue has been well depicted (Simpson \& Chapman, 1999). Hence processes of decision-making relating to urban conservation area boundaries are worthy of investigation to provide a more spatial and detailed observance on the processes of conservation area management and governance. Chinese heritage researchers have also noticed this, as the study of governance frameworks underpinning the enhancement of historic districts has just begun in China ( $\mathrm{Hu}, 2013$; He \& Deng, 2014). 
With this background, the paper aims to integrate reflections on conservation, agents and agency, and governance from a variety of domains of thought with a particular emphasis on the changing decision-making framework relating to conservation area boundaries. This is undertaken through the identification, analysis and reflection on the boundary changes of six conservation areas in Cardiff city centre from 1975 to 2012, mediated through wider research and experience of conservation areas in the UK. The studying time period is under consideration of the availability of documents and the change ein governance tof conservation areas in Cardiff city centre. In 1975 the first conservation area in Cardiff city centre was designated. In 2012, Welsh Labour gained control of Cardiff Council and further reforms waswere undertaken. Not all of the post-2012 documents after 2012 waswere available to the authors, therefore it is appropriate to use this as the end-date of could be proper tostop there in order to simplify the research. The time-tracking and the systematic study of the decision-making framework for changes to conservation area boundaries are the major features of this study. Deeper understanding about the agents behind the governance of conservation areas could facilitate a stronger connection between research and practice in relation to urban conservation areas; extending the evidence base of surveys of practice (Historic Environment Forum, 2017) and responding to issues of a wider lack of understanding of conservation (Larkham, 2000; Civic Voice, 2017) 


\section{The research focus}

\section{Clarification of the concepts}

The 'conservation area' considered in this paper is limited to UK conservation areas, of which the great majority (and the original but unstated intent of the 1967 Act) are settlement-based. Their legal definition is complex, with the paired terms 'architectural or historical', 'character or appearance' and 'preserve or enhance' having a long history of challenge (cf Larkham, 1996, chapter 4). What should be noticed, however, is that the 'character or appearance' could be a flexible definition and could be cited by local planning authorities to include plots and blocks that have undergone redevelopment. It could also be used to exclude features of apparent interest. This flexibility, and the variety of interpretations, underpinned the prominent debate on 'debasing the coinage' of definitions_designations in the 1990s (e.g. Morton, 1991). This paper focuses specifically on the conservation area; the wider conception of 'conservation planning' (Pendlebury, 2013) will not be discussed.

Governance, or the decision-making framework, as another important focus of this paper, commonly relates to the mix of all kinds of governing efforts by all manner of social-political actors, public as well as private (Kooiman, 2003). Thus -the governance of conservation areas may include governmental and non-governmental agents and those between, which could be termed advisory groups as most function in $\underline{\text { this way. }}$ 


\section{The case of Cardiff}

The decision to use Cardiff city centre for a time-series study of conservation area boundaries was shaped by the area's typicality (in relation to the 'core cities' of Pendlebury \& Strange, 2011, for example), the availability of a suitable group of close and changing designated areas, and the lack of existing research on its conservation although the city's regeneration has been well explored (Hooper \& Punter, 2007). As the largest city and political centre of Wales developed mainly in the Victorian timesperiod with a history traced back to the Roman occupation, Cardiff is very typical of industrial cities with cultural significance. Therefore the conservation of Cardiff could be strongly related to the regeneration of post-industrial urban economies and the governance of Cardiff conservation areas was likely to involve different forces and agents with complex inter-relationships.

Cardiff was made a county borough after the 1888 Local Government Act, and gained city status in 1905. Following the 1972 Local Government Act, in 1974

Cardiff became a district of South Glamorgan County (SGC) and lost its independent status. Most of the conservation area designations were made during this time when Cardiff City Council was subjected to the influence of South Glamorgan County Council. In 1996 Cardiff regained its independence when becoming a unitary authority with the abolition of SGC.

This paper studies the boundary changes of the six conservation areas in Cardiff city centre from 1975 to 2012, a period when the city started began its postindustrial regeneration and, at the same time, recognised the importance of the 
conservation of the historic environment. This is done by reviewing the publicly-

available historic documents of Cardiff Council (Table 1), comparison of the changing boundaries with the Ordnance Survey maps of Cardiff city centre 1975-

2012 which reflect the changing urban fabric, and interviewing a key decision-maker.

\section{The research approaches}

\section{Agent, agency and agent-network}

'Agency' is a widely-used although admittedly problematic concept. In sociology, for example, the term has 'maintained an elusive, albeit resonant, vagueness; it has all too seldom inspired systematic analysis' (Emirbayer \& Mische, 1998, p. 962). However, accepting these complexities in other disciplines, the idea as applied in planning and the closely-related field of urban morphology is simple. 'Agency' comprises the range of processes by which things happen in the urban landscape. This may be a decisionmaking process, where the decision-makers can be identified, the processes by which decisions are made can be explored, and the consequences for built form identified whether in the past, present or future. The study of urban landscapes has been linked more explicitly to the types of agents and the specific organizations and individuals responsible for their creation. 'Each pursues particular goals, the nature of which can result in conflict over the form of the built environment. It is important therefore to understand the motives underlying the behaviour of these key agents' (Pacione, 1991:162). Agents and their networks have been a focus of interest in the multinational and multi-disciplinary field of urban morphology and this method has been 
widely applied (Larkham, 2019). Whitehand established a method to study the evolution of individual plots by identifying agents and tracing actions from building plan applications, an approach which underpins this paper (Whitehand \& Whitehand, 1984; Whitehand, 1989). Gordon (1984) constructed a conceptual framework in which decision-makers were seen as 'actors' on the 'stage' of changing urban form although he also suggested 'decision agents' and 'contextual factors' as alternative terms less likely to imply active and passive roles. In the morphological tradition Larkham (1988) identified agents as 'direct' or 'indirect'. The direct groups included initiators of proposals, architects, site owners and specialist consultants. Indirect agents include local amenity groups, the public and local authority planning officers and committees, although subsequent work has emphasised the input of the planning system and of some individual planning officers, so in some circumstances they should perhaps be viewed as 'direct' agents. In the case of conservation area boundary change, the agents involved categorized as direct and indirect and their changing relationships could be very different.

It is important for this paper to specify the application of the method to study agents in the realm of environmental studies. They are commonly related to as 'actor factors' and agents are used to simulate multi-agent planning processes (Simon, 1996; Van Der Valk, 2002; Torrens, 2003; Ligtenberg et al., 2004). In other circumstances, agents are manipulated to form quantitative models (Gaube \& Remesch, 2013) on environmental issues. Similar research has been done in urban studies using cellular automata to simulate the process of urban planning and landscape generation (Batty, 
2009; De Landa \& Leach, 2009; Kuo \& Zausinger, 2010). The connections and interactions between agents that have been particularly emphasised in these investigations are essential underpinnings for the present research.

The 'agent' is also a core concept in the field of management and political science. The classification of agents into different types by their nature (instead of how they become involved in the decision-making process) could be important, and offers another way to investigate agents distinct from the 'direct-indirect' dichotomy. Lunenburg (2010), for example, has divided agents into 'outside pressure type', 'people-change-technology type', 'analysis-for-the-top type' and 'organizationdevelopment type'. This includes those who campaign, offer suggestions or make decisions. When related to the decision-making process for conservation areas, the relation to government could be a core consideration to distinguish different kinds of agents.

This paper seeks to utilize all the research methods on 'agent' discussed aboveto investigate the agents underpinning each of the decisions made on amending the boundaries of Cardiff city centre conservation areas. It attempts to divide those agents to both direct-indirect types and governmental, semi-governmental and nongovernmental types. The aims and interactions of those different types of agents and the extent of their influence on the final decisions is carefully discussed. On this basis a framework foren the connections of agents making decisions on the boundary changes in distinctive historical periods is developed. 


\section{Boundaries created by power and policy}

The conservation area considered here is, in fact, a specific public policy with spatial attributes. The spatial attributes of conservation areas show that the creation of these regions relates to the creation of their boundaries as demarcated by power (Barth, 2000; Jones, 2009). For example, the conservation area in the centre of the city of Durham, as depicted in 1980, included large 'green wedges' which were clearly not areas of special character or appearance - 'special' being a key term highlighted in the legislation and subsequent court challenges (Figure 1). The local planning authority made this inclusion to protect the views of the cathedral and castle. This highlights the importance of boundary-making in the governance of conservation areas: the study of boundary changes reflect the changing power exerted by different types of agents.

The public policy nature of conservation areas justifies the examination of the ways in which agents participate in the processes of generating public policies. The participation of agents in the decision-making processes may depend on their individual social status, the structure of the decision-making framework and the decision-making approaches that are customarily used by these agents (Sabatier, 2007). The specific process of policy-making is commonly seen as either the topdown imposition or the bottom-up practice (Ostrom, 2009). The creation of policies (e.g. the designation and review of conservation areas) may include both of these processes with different streams such as a problem stream, a (potential) policy stream, a politics stream (relating to national mood, pressure-group campaigning and 
administrative or legislative turnover) and the policy window (chances to put policies into practice) (Zahariadis, 2003).

Generally, the streams of policy-making and the structure of the decisionmaking framework may influence the power held by agents relating to the governance of conservation areas, which further leads to the impact that agents could exert on the boundaries of conservation areas. Therefore, theories on boundaries and boundarymaking, power and policy-making help to investigate the governance of conservation area boundary changes.

\section{Urban governance: production of space and urban marketing}

In order to further reflect the governance of Cardiff city centre conservation areas some important theories should also be considered. These include the production of space, urban marketing and theories on planning practice in Britain, all of which help to understand the main features of the governance of British cities from the 1970s to the 2010s. As mentioned by Lefebvre (1974), the production of space has become a major way to re-establish the productive relations in western cities. Therefore, the motif of urban governance or planning has changed to the competition about space wherein cities, the containers of space, became the main players of this game (Jessop, 1997; Malecki, 2002; Cochrane, 2003). They are "conceived as another capitalist product in that they are re-designed, commodified, packaged and then marketed/sold/traded as commodities to consumers in a marketplace" (Boland, 2007, p.24). Therefore the urban image, and associated key projects that help to create this 
image, becomes important for the development of cities.

In British planning practice, conservation has played an important part in the production of space and the marketing of cities in the post-war period. During 1970s and 1980s under Thatcher and Major, the influence of the market was almest over increasingly emphasised with the role of planning being reduced. Facing the centralized power of central government, local planning authorities (LPAs) found themselves able to exert less and less control, particularly following the establishment of 'enterprise zones' and 'simplified planning zones' which largely exempted businesses from the restrictions of local governments in terms of planning and business rates (Allmendinger \& Thomas, 1998; Allmendinger, 2016). Not until Labour won the 1997 election did the circumstances change. In this Conservativecontrolled period, conservation areas were, in fact, unusual in remaining fully under the control of LPAs (Larkham \& Barrett, 1998; Allmendinger \& Tewdwr-Jones, 1999). Despite this, it is clear that the role of conservation areas has changed. Before 1997 they were used as a major tool for the management of (limited) urban regions by LPAs, while after 1997 they gradually lost this special place.

\section{The shifting boundaries}

\section{Changing conservation areas and the associated documentation}

In 1975 the first of six conservation areas in Cardiff city centre was designated

(Figure 2) and the last amendment to their boundaries occurred in 2009. The designation and amendment activity was not evenly distributed over time, but tend to 
be clustered at points of socio-economic change. Committee reports cluster around 1975 and 1983, while the 1990 Planning (Listed Buildings and Conservation Areas) Act resulted in a cluster of reviews and strategies around 1992 (Figure 3). This is closely related to the pattern of designation and review activity in England (Larkham, 1996).

There is a specific pattern in the number of conservation areas and boundary changes in documents before and after 1990. Committee reports were only made to discuss boundary changes before 1990, resulting in the number of conservation areas mentioned and the boundary changes made being almost the same. The 1990 Planning (Listed buildings and Conservation Areas) Act re-emphasised the need for conservation areas to be reviewed regularly. Therefore reviews and strategies undertaken after 1990 were made mostly to evaluate conservation areas, leading to more conservation areas being mentioned in formal documentation although with little change made to them.

\section{Tracking conservation areas in Cardiff city centre}

The city centre of Cardiff includes a castle, the civic centre to its north, which was once the administrative centre of Cardiff, and the medieval old town to its south. St Mary Street Conservation Area (previously known as Central Area Conservation Area No. 1) and Windsor Place Conservation Area (Central Area Conservation Area No. 2) were the first to be designated, in 1975. Queen Street Conservation Area was the last designated, in 1992. 
St Mary Street conservation area: the expanding boundaries

St Mary Street was first considered for designation as a conservation area in 1975, following a suggestion from the Victorian Society in a letter to the Planning and Development Committee (PDC) on 2nd December, 1974. The City Planning Öefficer made a broad study of Cardiff city centre and identified St Mary Street, High Street and Church Street as containing 'outstanding value'. Buildings both inside and outside the area which the report suggested designating were studied. The City Planning Officer identified St John's Church, Hayes Island, the northern part of St Mary Street and High Street as well as façades fronting High Street, St Mary Street and Castle Street as having strategic importance for designation, all of which were located in the north part of the whole area. The southern part of St Mary Street, however, was assessed as not having the quality required for designation and several redevelopment applications were focused on this area and were approved (see, for example, planning applications for the [listed] Prince of Wales Theatre, 65-74 St Mary Street, and 16-17 High Street). Consequently, in the committee report the City Planning Officer suggested that the south part of St Mary Street should not be part of the new conservation area. These suggestions were approved and Central Area Conservation Area No. 1 was designated in July 1975.

Seven years afterwards, a letter from the Secretary of the Victorian Society to the City Council on 15th November, 1982 requested the extension of the conservation area to include lower St Mary Street. The committee report of February 1983 echoed the letter by reviewing the building quality of the west side of lower St Mary Street. 
Under pressure from Victorian Society and given that the redevelopments were completed, the west side was recommended for designation. The east side, however, was regarded as not having | the unity of scale of the west side and contains far fewer buildings of merit', despite the acknowledgement of the positive effect on the overall townscape of St Mary Street. The report used phrases such as 'awkward triangular shaped block' and 'variable architectural quality of the frontage' (Cardiff City Council, 1983). PDC accepted these suggestions and only the west side of the southern end of St Mary Street was added to the conservation area.

In 1984 Lock-Necrews Hill and Partners requested another alteration to Central Area Conservation Area No. 1. They were Chartered Architects undertaking refurbishment works on 13-23 Westgate Street $_{2}$ and the extension could encourage their potential clients by raising rents. In response, the planning officer reported on the potential for extending the boundary to incorporate 3-25 Westgate Street, where the rear elevations of buildings with important front façades mentioned in the 1975 report were situated. Thanks to the 1975-84 environmental improvements, this area had acquired the quality to be considered for conservation area status. Therefore, 'the whole of Womanby Street and the east side of Westgate Street north of Quay Street' (Cardiff City Council, 1984) was proposed for inclusion. This was further supported by the Central Area Conservation Group. The area finally included was a little larger than the original proposal, including the east side of Womanby Street (Figure 5).

In 1988 a planning application for the redevelopment of Wyndham Arcade caused great protest. The applicants applied to Cadw for a Certificate of Immunity
Commented [PL3]: Need to check consistency / journal style of single or double quote marks 
from listing, which perhaps went beyond the intentions of the city council.

Consequently, local traders, Ward Members and the public asked the city council to reject the planning application (Cardiff City Council, 1988a). The Traders Association requested an extension of Central Area Conservation Area No. 1 to include the block of properties around the redevelopment site. Amenity groups including Cardiff 2000 (which later became the Civic Society) and the Wyndham Arcade Traders Association sought to persuade Cadw to recommend that the Arcade should be listed. The City Planning and Development Officer (the name title has $\underline{d}$ changed since 1984) and the conservation group therefore studied Wyndham Arcade, Caroline Street, southern St Mary Street and Mill Lane. They reached the same conclusion as the 1983 report: that the architectural quality was mixed and the buildings not worth individual consideration. However, due to their contribution to the overall townscape of the city centre, their sensitive location and the emphasis on conservation initiatives from the City Council, an extension to the boundary could ensure that the setting of the area and of individual buildings was not adversely affected by 'inappropriate development'. Consequently, the City Planning and Development Officer suggested a boundary extension to include the 'block bounded by the eastern side of lower St Mary Street, Mill Lane and Caroline Street, including Brains Brewery and the northern side of Caroline Street' (Cardiff City Council, 1988a) and this was accepted.

The 1992 Conservation Strategy made changes to boundaries of conservation area in Cardiff as a whole. Proposal No. 4 requested that Central Area Conservation Area No. 1 be enlarged to include both sides of Westgate Street to retain the integrity 
of the street view (City of Cardiff, 1992a). Following the strategy, the 1992 review made further alterations. Besides changing the name to 'St Mary Street conservation area', it suggested, and later approved, that the western side of Westgate Street from Castle Street to Park Street should be considered for inclusion. This was later approved. The east side of St Mary Street conservation area was also expanded, though to a very limited extent, to include both sides of the Hayes (City of Cardiff, 1992b).

After 1997, conservation gradually seems to have lost its place in the governance of Cardiff city centre. After 1992 sixteen years passed without any formal documentation mentioning conservation area boundaries. The only two reviews, made in 2006 and 2009 respectively (Cardiff Council, 2006; Cardiff Council, 2009), contain no evidence of any change made to the existing boundaries. However, the current boundaries shown on official maps and the website of Cardiff Council are subtly different from the 1992 boundaries, specifically on The Hayes in the east and the junction of Wood Street and Westgate Street in the west (Figure 4). This could possibly be the result of technology change and data transfer rather than intentional alteration.

\section{Boundaries of the other city-centre conservation areas}

Several other conservation areas in Cardiff city centre demonstrate the impressive changes made to conservation area boundaries. The boundary changes to Windsor Place Conservation Area eome as thecame firstexample (Figure 6). In 1988, the 
conservation group recommended the extension of the south boundary of the area to protect some buildings from redevelopment in Queen Street, which became the focus of development plans (Morgan, 1991; Hooper \& Punter, 2007), and where a regional commercial attraction was proposed. PDC accepted this suggestion and resolved to extend Windsor Place to include area around the Park Hotel, which had been listed in 1974. In 1992, when the Queen Street redevelopment had been completed, the Queen Street protection buffer was removed and incorporated into the new Queen Street conservation area.

Cathays Park (Figure 7) was not considered for designation in 1975, as most of the buildings in the studied area were statutorily or provisionally listed and all of the land was in the ownership of the local authority or governmental bodies. This followed the idea that designation should serve a policy purpose, not be made for the sake of designating: the listing and landownership would provide sufficient protection (a common view at the time). The area's designation in 1978 resulted from a changed circumstance, the effect of Dutch Elm disease, as the planning officer suggested that designation would facilitate Central Government grants for the planting of replacement semi-mature lime trees. A large additional area including Bute Park and Park Place were designated to 'give the City Council control over the demolition of buildings, which are not protected by listed building status' (Cardiff City Council, 1978), although in 1975 it had been felt that their lack of unified character made them unsuitable for designation. Again, the apparent use of conservation designations as 'demolition control areas' was common at the time. 
Charles Street tells a different story in more recent years, when conservation planning gradually lost its place (Figure 8). The conservation area was designated to gain control over plots purchased by South Glamorgan County Council for the widening of Bridge Street (and perhaps even to stop SGCC's plans, see Cardiff City Council, 1988b). After the final designation in October 1988 the boundary of Charles Street Conservation Area never changed. However, the plot structure and landscape character have changed dramatically since 2006, when the demolition of Wesley Hall and annexes was approved. Four years after 2012later, in 2016, the approval of another application for construction of the new Bridge Street Exchange radically changed the character of the conservation area (Cardiff Council, 2016). This 24-floor commercial building straddles the area boundary, overshadowing the Victorian terraces and churches in the core of the conservation area (Figure 9). Surprisingly, there has been no review to deal with this fact and the south boundary has remained unchanged despite the drastic alteration of the plots and, therefore, of the character of the designated area.

\section{The full profile of the boundary changes}

All of the boundary changes and crucial events accompanying them are represented in Figure 10, which shows that some of the conservation areas have experienced expansion during the 1970s and 1980s. St Mary Street and Cathays Park are two clear examples. As for Windsor Place, there was a shrinkage in the 1992 boundary change but, since this change was to facilitate the creation of the Queen Street conservation 
area, the total area covered by the two conservation areas grew larger. In fact

Churchill Way is the only conservation area that remains unchanged in Cardiff city centre throughout the period studied. Charles Street conservation area shrank in 1988 due to the fact that the boundary was designated (in June) before a building application submitted earlier could be viewed (Cardiff City Council, 1988b): PDC was, apparently, in too much of a hurry to get the conservation area designated. Therefore, virtually all of the conservation areas in Cardiff city centre have expanded at least a little, but the problem is why the process of review and expansion stopped after 1992. Between 1992 and 2012 there was only two conservation area reviews, one on St Mary Street while the other covered the remaining five conservation areas. Neither review made any change to the area boundaries.

However, there is a more fundamental question: why were the boundaries of Cardiff city centre conservation areas persistently expanding before 1992? The expansions were not always specifically for the protection of historic character or appearance, as is encouraged by the Civic Amenities Act and its successors. To answer this question it is necessary to carefully investigate the decision-makers for each of the expansions: who promote the boundary changes, and for what reasons?

\section{Agents: the creators of boundary change}

\section{Different types of agents in the governance of conservation areas}

This paper divides agents in the conservation area decision-making process into governmental, semi-governmental and non-governmental categories. The 
governmental agents act on three distinct levels: city, county and the national level. Among these agents the Planning and Development Committee, Executive Business Meeting (currently the cabinet), Planning Policy Committee (now no longer existextant) and the Cardiff City Council itself could be identified as direct agents. PDC and EBM make final decisions on conservation areas (though they operate in different historic periods) while the council and PPC check whether these decisions are appropriate. The rest of the departments and institutions in Cardiff Council, the South Glamorgan County Council as well as institutions on Welsh national level_ (particularly the Welsh Development Agency which gave grants to local government), are identified as indirect agents.

The semi-governmental agent category relates directly to the Conservation Group, which was set up based on Welsh Office Planning Circular 61/81. Conservation groups consist of councillors, conservation area representatives and members of social groups (or non-governmental agents, see Table 3). Among all of the conservation groups in Cardiff, the Central Area Conservation Group is responsible for conservation areas in Cardiff city centre. It works as an advisory group for Cardiff Council and is appointed by PDC. Before 1999, the conservation group drafted the policy for conservation areas and their boundaries, which makes it a direct agent along with the governmental agents. However, it lost this place after the political reform of Cardiff Council in 1999 and became an indirect agent, a group with much less influence on the decision-making process for conservation areas. In 
2012, when Labour again won the local election, the funding of conservation groups was cut, and most of them are no longer constituted by Cardiff Council .

The non-governmental agents are those outside the governmental system, including the Victorian Society, Cardiff Civic Society, traders' associations, wards and communities and groups of architects or developers. All are indirect agents and cannot make policy decisions. They may seek to influence decisions by writing to Cardiff Council, campaigning against certain polices or taking part in the conservation group through the efforts of their representatives.

\section{The purposes of agents when making decisions}

When making boundary changes, agents of different types have distinct purposes, mostly for their own benefits. These aims could act against each other and, if this is the case, those who possess greater power will make the final decision.

Governmental agents, particularly the PDC or the Planning Department after 1999, expand conservation areas (or designate new ones) generally for three reasons. They are to seek more grants from national government, to seek more control over urban spaces (specifically against proposals from SGCC), or for the implementation of requirements of higher-level governmental bodies. The impressive expansion on the boundary of Cathays Park conservation area in 1978 shows how PDC used this to secure more funding from the national government. In order to get enough-grant funding for re-planting trees around Cathays Park - which had been hard hit by Dutch Elm Disease-related tree deaths, and the trees had formed an important aspect of the 
area's character - the PDC expanded the conservation area to include almost everywhere that trees were growing. The boundary extended to the river Taff in the west and to almost the edge of Cathays Park (Queen Anne Square) in the north, regions where woodland was situated. The designation of Charles Street, in addition, reflects the conflict between Cardiff City Council and the South Glamorgan County Council. Even though the latter is at a higher level in the governmental hierarchy, SGCC has to follow the wishes of Cardiff City Council relating to potential development inside conservation areas. Therefore the city council was motivated to designate more conservation areas to stop SGCC from promoting developments that were unwanted by the city. In 1988 the city council referred to the SGCC's purchase of Nos_-_63 and 65 Charles Street for the widening of Bridge Street (Cardiff City Council, 1988b). The designation was, to a certain extent, intended to give some control over the demolition of buildings on Charles Street and therefore to stop SGCC from carrying out its intentions (Figure 11).

Semi-governmental agents, the conservation group, often take part in the work of implementing requirements. The designation of Charles Street and expansion of Windsor Place (Central Area Conservation Area No. 2) in 1988 was also, in part at least, to implement requirements from the Welsh Office. A similar purpose was behind the 1992 review. With help from the conservation group, which focuses solely on conservation itself, when the expansion of conservation area boundaries was for wider policy implementation reasons, the specific conservation aims are strengthened. 
It could be concluded that the conservation group in very helpful in ensuring that governmental decisions retain a specific conservation rationale.

Non-governmental agents have two opposite purposes when asking for boundary expansions. Some of these agents are reaching out to conservation, while others are using the conservation area as a tool for the exchange of benefit with governmental agents. On the one hand, the Victorian Society, Cardiff Civic Society, trade associations, wards and communities are agents of the former type. They suggest, campaign or send representatives to the council (or éConservation gGroup) to get where they live or work designated as conservation areas. The designation could better their living environment or raise property or rent values - there is often a degree of self-interest in responses from some such groups - so that they could be benefit. The 1988 extension of St Mary Street conservation area to Wyndham Arcade is a good example. The conservation area was extended to include areas where Cardiff City Council thought that the character and historic value did not qualify for conservation area status. On the other hand, architects and developers' groups are of the latter type. They work together with governmental agents to secure development in the city centre using the conservation area boundary as a tool. They will work on plots both inside and outside the designated area. The restrictions within designated areas mean that work within them is more likely to consist of enhancement, and plots outside are more likely to be subject to redevelopment. Therefore the plots outsidecould be more suitable for larger-scale development such as shopping malls, office buildings and apartments. But once that development is complete, developers may 
seek the extension of conservation area boundaries and the local authority,

considering their efforts to enhance the urban core (e.g. Jones Court), may permit this kind of application. However, under pressure from the conservation group and nongovernmental agents such as the Victorian Society, the nature of redevelopment proposals outside conservation areas has had to retain some conservation-related features in order to get permission. This promoted 'façadism', a form of redevelopment in which only the façade of historic building is retained (Richards, 1994). Large commercial buildings on south St Mary Street, Queen Street and the north end of Westgate Street represent this type of development: all are now inside conservation area boundaries but few retain much intrinsic historic value (Figure 12).

\section{The decision-making framework}

An interview with the current leader of Cardiff Council's placemaking group helped unravel the complexity of the conservation area decision-making framework and its changes over time revealed in the formal documentation. The documents show that, before 1999, the decision-making style was essentially a form of cooperation between several direct agents. The Conservation Group made the draft boundary changes, PDC transformed it into formal policy documents which were reviewed by the Planning Policy Committee and the full Council. The latter two agents could give instructions and require PDC and Conservation Group to make alterations to their recommended policies. Generally this is a circular and negotiation-based way to make decisions

(Figure 13). In 1999 there were reforms to the governance of conservation areas and 
the previously-separated decision-making institutions were integrated into the newlyfounded Executive Business Meeting (after 2012 the EBM changed its name to the Cabinet). The Conservation Group lost its place as a direct agent and all the issues relating to conservation areas were transferred to EBM. EBM communicated directly to non-governmental agents and responded to their needs (Figure 14). This reform raised the efficiency of decision-making but, at the same time, weakened the power of

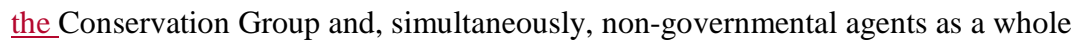
since they lost their leader in fights against governmental agents and their collaborators. Therefore, the governmental agents gained more power over the Conservation Group and non-governmental groups, making conservation areas less able to resist pressure for development. In fact, even the façadism form of regeneration was abandoned and more and larger-scale structures arose in Cardiff city centre apparently regardless of whether they were inside, on the edge of, or near to a conservation area. This includes the Millennium Stadium, St David's II and the Central Square now under construction. The difference before and after 1999 is very clear, and the extent and impact of redevelopment is emphasised if all of the area boundaries and rebuilding projects are mapped (Figure 15).

This paper now is able to address the problem raised earlier: in the example of Cardiff it was the growing power of the governmental agents that stopped the expansion of conservation areas, which had been manipulated partly as a way in the 1970s and 1980s - through façadism - for regeneration of the Victorian city centre. In the 1990s the 'giant architecture' replaced façadism in the redevelopment of 
Cardiff city centre thanks in part at least to the growing power of Cardiff Council and the diminished influence of other agents.

\section{Whogives the power to The origin of Cardiff Council's power?}

The origin of the powers exercised by the governmental agents (Cardiff Council) either to support conservation or to promote development is worth considering given the pattern of decision-making over time. Obviously the key source is Parliamentary legislation, so changes in legislation, administration and planning should be considered. Yet changing conservation legislation has had limited impact on conservation practice; comparing the 1974 legislative system ${ }_{1}^{1}$ and the 1990 system $_{3 .}^{2}$; the increased emphasis on the 'regular review' of conservation areas by LPAs is the only significant change; many of the key sections have retained very similar wording from 1971 or even 1967.

The changing administration of Cardiff, and perhaps even Wales, could be a more significant factor. As has been pointed out, Cardiff was a district of SGC after the local government reorganization in 1974. The existence of SGCC, the influence of the Welsh Office and the Westminster government's regulations on limiting local plans all squeezed the planning power of Cardiff City Council. It could be argued that

1 This includes the 1974 Town and Country Amenities Act, the amended 1971 Town and Country Planning Act and related Welsh Circular 147/74 (Welsh Office 220/74) (DoE 1974) and Circular 53/67 (MoHLG 1967).

2 This includes the 1990 Planning (Listed Building and Conservation Areas) Act, the 1990 Town and Country Planning Act and some related orders or circulars. 
almost the only place where the city council's planning power remained strong was within designated conservation areas. Therefore the utilization of conservation areas by governmental agents as a regeneration tool was actually a temporary expedient since it was inevitable that there would be some compromise to non-governmental agents. When Cardiff became a unitary authority in 1996 with the abolition of SGCC, conservation areas were no longer needed to facilitate regeneration or redevelopment of more city-centre spaces. The power of the city council was further strengthened after devolution when the new Welsh government was eager to demonstrate its power. One way to do this at that time was to support Cardiff Council in creating landmark projects that could represent Wales. Together this gave birth to the 'European capital' strategy (Punter, 2007) put forward by Russell Goodway, the then council leader. This strategy underpinned the construction of 'giant architecture' in the 1990s and the first five years of the 2000s, and the marginalization of conservation areas.

The planning system does not have the same impact as administration. It sets the framework for an individual LPA's conservation-related activities, but does not specify what must be done, how or when. During 1975-1999 plans for Cardiff were made either by the Welsh Development Agency (WDA) or SGCC, while during 1999-2012 more conservation- and development-related plans were made by Cardiff Council. After 1996 the Unitary Development Plan (Coop \& Thomas, 2007; City \& County of Cardiff, 1997) became an important factor for conservation decisionmaking, and both of the only two reviews undertaken after 2000 were related to the process of creating the Cardiff Local Development Plan 2006-2026. This is to say that; planning, itself could reflect the reality of the power shifting from the WDA and SGCC to Cardiff Council, but was unable to promote this shift. 


\section{Discussion and Conclusion}

This paper reveals a short part of the history of conservation planning in the UK, using Cardiff as a case study. Conservation is deeply embedded in governance and the decision-making process related to it, with integral links with property rights and land policy. This paper identifies the centralization of decision-making and the diminution of governance on the specific issue of conservation (Figure 16), which may be a result of the changes in the locus of power in the UK particularly between the central, regional and local levels.

This paper has examined the timeline for, and changes to, Cardiff's city-centre conservation areas and tracked the continuing expansion of each of the conservation areas between 1975 and 1992. Investigation of the agents making decisions on conservation area boundaries has identified the reasons underlying these boundary extensions, and why this extension process stopped after 1992. By categorizing agents into both governmental, semi-governmental and non-governmental, and directindirect, the paper identifies the decision-making framework of conservation areas in Cardiff city centre. The expansion of conservation area boundaries during 1975-1992 was very clearly prompted by two opposite forces: façadism (promoted by governmental agents and a small group of non-governmental agents, especially architects and developers) and the calls for conservation (promoted by Conservation Groups and most non-governmental agents). After 1992 the expansion process was halted, since the city council acquired more power to develop and façadism was no longer needed. The more powerful city council also weakened the Conservation which case "the Conservation Group" 
Groups (even to the point of disbanding them in 2012) and, due to financial cutbacks affecting some of Cardiff's non-governmental agents, their influence became more limited.

The attribution-suggestion that conservation areas in Cardiff city centre became less significant, with less review and no extensions, after 1992 solely to the growing power of Cardiff Council should be mediated by acknowledgement of the large-scale waves in society and the economy in western cities. The global economic crisis led to quiescence, where active conservation planning may have stood aside in part because the direct threat of demolition and redevelopment, and other changes, also became less significant. During periods of intense development pressure, conservation may be more intensively used as an area improvement or development management tool, as in Cardiff during 1975-1992. Alternatively it may be seen as a barrier to continued economic growth, and side-lined, as happened after 1992. However, it would be hard to deny the influence of Cardiff Council since the 'European capital' strategy and the construction of large complexes changed very little in Cardiff city centre before and after the economic crash in 2008. Consequently, there is a need for further studies on positioning conservation planning in urban governance to strengthen urban landscape management, to reinforce character and identity, and support the development of cities in the emerging era of global economies and cultures.

Word count: 7709

Commented [PL7]: Delete this unless the journal asks for it! 


\section{Disclosure statement}

No potential conflict of interest was reported by the authors.

\section{Funding}

There is no funding to report for this study.

\section{ORCID}

https://orcid.org/0000-0002-2456-958X(to be supplied) (Peter J Larkham)

\section{Acknowledgement}

Particular thanks are due to Mr Ross Cannon, leader of the placemaking group of Cardiff

Council who made available council documents and practical knowledge on the decisionmaking framework of conservation areas in Cardiff. Cardiff Council, Cathays Branch and

Heritage Library and Glamorgan Archives gave access to their collections of historical documents and maps. The advice offered by Professor J.W.R. Whitehand and Mrs Y. Shi of the University of Birmingham is appreciated.

\section{References}

Abbott, A. (1995) Things of boundaries, Social Research, 62, pp. 857-882.

Allmendinger, P. (2016) Neoliberal Spatial Governance (New York: Routledge). Allmendinger, P. \& Tewdwr-Jones, M. (1999) New Labour, new planning? The trajectory of planning in Blair's Britain, Urban Studies, 37(8), pp. 1379-1402.

Allmendinger, P.; Thomas, H. (1998) Planning and the New Right, in: P. Allmendinger \& H. Thomas (Eds) Urban Planning and the British New Right (London: Routledge).

Avelino, F. \& Rotmans, J. (2009) Power in transition: an interdisciplinary framework to study power in relation to structural change, European Journal of Social Theory, 12(4), pp. 543-569.

Ashworth, G. \& Graham, B. (Eds) (2005) Senses of Place: Senses of Time (Aldershot: Ashgate).

Barth, F. (2000) Boundaries and connections, in: A. Cohen (Ed.) Signifying Identities: Anthropological Perspectives on Boundaries and Contested Values, pp. 17-36 (London: Routledge). 
Bienstman, H. (2007) Morphological concepts and urban landscape management: the cases of Alkmmaar and Bromsgrove (Doctoral dissertation) University of Birmingham.

Birkhamshaw, A. J. \& Whitehand, J. W. R. (2012) Conzenian urban morphology and the character areas of planners and residents, Urban Design, 17, pp. 4-17.

Boggs, W. (1932) Boundary functions and the principles of boundary making, Annals of the Association of American Geographers, 22, pp. 48-49.

Boland, P. (2007) Competitive cities: unpacking the theoretical debates, in: A. Hooper $\&$ J. Punter (Eds) Capital Cardiff 1975-2020: Regeneration, Competitiveness and the Urban Environment, pp. 17-30 (Cardiff: University of Wales Press).

Cadw (2017) Managing Conservation Areas in Wales, Cardiff: Cadw.

Cardiff City Council (1975) City Planning Officer's report to Planning and Development Committee $10^{\text {th }}$ January (Cardiff: Cardiff City Council).

Cardiff City Council (1978) City Planning Officer's report to Planning and Development Committee $2^{\text {nd }}$ May (Cardiff: Cardiff City Council).

Cardiff City Council (1983) City Planning Officer's report to Planning and Development Committee $11^{\text {th }}$ February (Cardiff: Cardiff City Council).

Cardiff City Council (1984) City Planning and Development Officer's report to Planning and Development Committee $7^{\text {th }}$ December (Cardiff: Cardiff City Council).

Cardiff City Council (1988a) City Planning and Development Officer's report to Planning and Development Committee $10^{\text {th }}$ May (Cardiff: Cardiff City Council).

Cardiff City Council (1988b) City Planning and Development Officer's report to Planning and Development Committee $30^{\text {th }}$ June (Cardiff: Cardiff City Council).

Cardiff City Council (1988c) City Planning and Development Officer's report to Planning and Development Committee $11^{\text {th }}$ October (Cardiff: Cardiff City Council).

Cardiff Council (1997) Conservation Area Strategy (Cardiff: Cardiff Council).

Cardiff Council (2004) Planning Committee's report of the check to the council on the

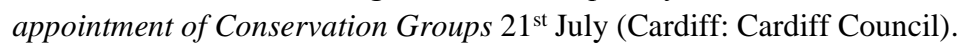

Cardiff Council (2006) Corporate Director's report to the Executive Business Meeting on St. Mary Street Conservation Area Appraisal 1 1 $1^{\text {th }}$ April (Cardiff: Cardiff Council).

Cardiff Council (2009) Corporate Director's report to the Executive Business Meeting on Cathays Park, Charles Street, Churchill Way, Queen Street and Windsor Place Conservation Area Appraisals $1^{\text {st }}$ April (Cardiff: Cardiff Council). 
Cardiff Council (2010) Report on Appointment of Conservation Groups from the Clerk to the Council and Planning Committee $14^{\text {th }}$ July (Cardiff: Cardiff Council).

Cardiff Council (2010) Planning Committee's report of the check to the council on the appointment of Conservation Groups $14^{\text {th }}$ July (Cardiff: Cardiff Council).

Cardiff Council (2011) Chief Officer Legal \& Democratic Services report on Appointment of Conservation Groups to Cardiff Council and Planning Committee $13^{\text {th }}$ July (Cardiff: Cardiff Council).

Cardiff Council (2016) Permission for Development $11^{\text {th }}$ July (Cardiff: Cardiff Council).

Cardiff Council (2016) Planning Obligation by Agreement $11^{\text {th }}$ July (Cardiff: Cardiff Council).

City of Cardiff (1992a) A Conservation Strategy (Cardiff: City of Cardiff).

City of Cardiff (1992b) Central Area Conservation Area Boundaries Review to Planning and Development Committee $27^{\text {th }}$ February (Cardiff: City of Cardiff).

City of Cardiff (1993) Churchill Way Conservation Area Planning Brief (Cardiff: City of Cardiff).

Civic Voice (2017) Big conservation conversation, available at www.civicvoice.org.uk/campaigns (accessed 11 October 2019).

Cochrane, A. (2003) The social construction of urban policy, in: G. Bridge \& S. Watson (Eds) A Companion to the City, pp. 531-542 (Oxford: Blackwell).

Coop, S. \& Thomas, H. (2007) Planning doctrine as an element in planning history: the case of Cardiff, Planning Perspectives, 22(2), pp. 167-193.

DoE (Department of the Environment) (1974) Town and Country Amenities Act, Circular 147/74 (Welsh Office 220/74) (London: HMSO).

Deadman, P. (1999) Modelling individual behaviour and group performance in an intelligent agent-based simulation of the tragedy of the commons, Journal of Environmental Management, 56(3), pp. 159-172.

Emirbayer, M. \& Mische, A. (1998) What is agency? American Journal of Sociology, 103(4), pp. 962-1023.

Gaube, V. \& Remesch, A. (2013) Impact of urban planning on household's residential decisions: An agent-based simulation model for Vienna, Environmental Modelling \& Software, 45, pp. 92-103.

Gordon, G. (1984) The shaping of urban morphology, Urban History, 11, pp. 1-10. Historic Environment Forum (2018) Heritage Indicators 2018 (Swindon: Historic England).
Commented [PL8]: 2010a, b-distinguish in text too

Commented [PL9]: If this is a specific grant of planning permission, would help to have the site address or application number

Commented [PL10]: 2016a, b - distinguish in text too 
Historic Environment Forum (2017) Heritage Counts 2017: 50 Years of Conservation Areas (Swindon: Historic England).

Hooper, A. \& Punter, J. (Eds) (2007) Capital Cardiff 1975-2020: regeneration, competitiveness and the urban environment (Cardiff: University of Wales Press).

Jones, R. (2009) Categories, borders and boundaries, Progress in Human Geography, 33(2), pp. 174-189.

Jessop, B. (1997) The Entrepreneurial City: Re-imaging localities, redesigning economic governance, or restructuring capital? In: N. Jewson \& S. MacGregor (Eds) Transforming Cities. Contested Governance and New Spatial Divisions, pp. 28-41 (London, Routledge).

Kain, R. J. P. (1982) Europe's model and exemplar still? The French approach to urban conservation, 1962-1982, Town Planning Review, 53(4), pp. 403-422.

Kooiman, J. (2003) Governing as governance (London: SAGE).

Kozlowski, J. \& Vass-Bowen, N. (1997) Buffering external threats to heritage conservation areas: a planner's perspective, Landscape and Urban Planning, 37, pp. 245-267.

Lai, P. H. \& Kreuter, U. (2012) Examining the direct and indirect effects of environmental change and place attachment on land management decisions in the Hill Country of Texas, USA, Landscape and Urban Planning, 104, pp. 320-328.

Larkham, P. J. (1988) Agents and types of change in the conserved townscape, Transactions of the Institute of British Geographers, NS13(2), pp. 148164.

Larkham, P. J. (1996) Conservation and the City (London, Routledge).

Larkham, P. J. (1990) Conservation and the management of historical townscapes, in: T. R. Slater (Ed.) The Built Form of Western Cities: Essays for M. R. G. Conzen on the Occasion of his Eightieth Birthday, pp. 349-367 (Leicester: Leicester University Press).

Larkham, P. J. (1996) Designating conservation areas: patterns in time and space, Journal of Urban Design, 1(3), pp. 315-327.

Larkham, P. J. (1997) Conservation areas: ideal and reality reviewed, Transactions of the Ancient Monuments Society, 41, pp. 23-43.

Larkham, P. J. (2000) Residents' attitudes to conservation, Journal of Architectural Conservation, 6(1), pp. 73-89.

Larkham, P. J. (2019) Agents and Agency in the Urban Landscape, in: V. Oliveira (Ed.) J.W.R. Whitehand and the Historico-geographical Approach to Urban Morphology, pp. 67-90 (Cham: Springer). 
Larkham, P. J.; Barrett, H. (1998) Conservation of the built environment under the Conservatives, in: P. Allmendinger \& H. Thomas (Eds) Urban Planning and the British New Right, pp. 53-86 (London: Routledge).

Larkham, P. J. \& Morton, N. (2011) Drawing lines on maps: morphological regions and planning practices, Urban Morphology, 15(2), pp. 133-151.

Ligtenberg, A., Wachowicz, M.. Bregt, A.. Beulens, A. \& Kettenis, D. (2004) A design and application of a multi-agent system for simulation of multi-actor spatial planning, Journal of Environmental Management, 72(1-2), pp. 43-55.

Lunenburg, F. C. (2010) Managing change: the role of the change agent, International Journal of Management, Business, and Administration, 13(1), pp. 1-6.

Lunenburg, F. C. (2012) Organizational structure: Mintzberg's framework, International Journal of Scholarly, Academic, Intellectual Diversity, 14(1), pp. $1-8$.

Malecki, E. (2002) Hard and soft networks for urban competitiveness, Urban studies, 39(5-6), pp. 929-945.

McDowell, S. (2016) Heritage, memory and identity, in: B. Graham \& P. Howard (Eds) The Ashgate Research Companion to Heritage and Identity, pp. 37-53 (Aldershot: Ashgate).

MoHLG (Ministry of Housing \& Local Government) (1967) Historic Towns: Preservation and Change, Circular 53/67 (London: HMSO).

Minghi, J. (1963) Boundary studies in political geography, Annals of the Association of American Geographers, 53(4), pp. 407-428.

Morgan, D. (1991) The Cardiff story (Bridgend: Brown).

Morton, D. (1991) Conservation areas: has saturation point been reached? The Planner, 77(17), pp. 5-8.

Ostrom E. (2009) "Governing the Commons": The evolution of institutions for collective action. Paper presented at the Seminar on Political Ecology, July.

Pacione, M. (1991) Development pressure and the production of the built environment in the urban fringe, Scottish Geographical Magazine, 107, pp. 162169.

Pendlebury, J. (2009) Conservation in the Age of Consensus (Abingdon: Routledge).

Pendlebury, J. \& Strange, I. (2011) Urban conservation and the shaping of the English city, Town Planning Review, 82(4), pp. 361-392.

Pendlebury, J. (1999) The conservation of historic areas in the UK: A case study of “Grainger Town”, Newcastle upon Tyne, Cities, 16(6), pp. 423-433. 
Planning Portal (2019) Conservation area guides (Northern Ireland). available at www.planningni.gov.uk/index/policy/planning_statements_and_supplementary_ planning_guidance/conservation (accessed 11 October 2019).

Punter, J. (2007) A City centre for a European capital? In: A. Hooper \& J. Punter (Eds) Capital Cardiff 1975-2020: Regeneration, Competitiveness and the Urban Environment, pp. 122-148 (Cardiff: University of Wales Press).

Richards, J. (1994) Facadism (London: Routledge).

Sabatier, P. A. \& Weible, C. M. (2007) The advocacy coalition framework, in: P. A. Sabatier (Ed.), Theories of the Policy Process, pp. 189-220 (Boulder: Westview).

Scrase, A. (1991) Archaeology and planning - a case for full integration, Journal of Planning and Environment Law, December, pp. 1103-1114.

Scottish Executive, Development Department (2019) A Guide to Conservation Areas in Scotland. available at www2.gov.scot/Resource/Doc/37428/0009675.pdf (accessed 11 October 2019).

Simon, H. A. (1996) Sciences of the Artificial (Cambridge, MA: MIT Press).

Simpson, F. \& Chapman, M. (1999) Comparison of urban governance and planning policy, Cities, 16(5), pp. 353-364.

Strange, I. \& Whitney, D. (2003) The changing roles and purposes of heritage conservation in the UK, Planning, Practice \& Research, 18(2-3), pp. 219-229.

$\mathrm{Su}, \mathrm{X}$. (2010) Urban conservation in Lijiang, China: Power structure and funding systems, Cities, 27, pp. 164-171.

Torrens, P. M. (2003) Cellular automata and multi-agent systems as planning support tools, in: S. Geertman \& J. Stillwell (Eds) Planning Support Systems in Practice, pp. 205-222 (Berlin \& Heidelberg: Springer).

Van der Valk, A. (2002) The Dutch planning experience, Landscape and Urban Planning, 58(2-4), pp. 201-210.

Whitehand, J.W.R. (1989) Residential development under restraint: a case study in London's rural-urban fringe, Occasional Publication No.28, School of Geography (Birmingham: University of Birmingham).

Whitehand, J. W. R. (2009) The structure of urban landscapes: strengthening research and practice, Urban Morphology, 13(1), pp. 5-27

Whitehand, J. W. R. \& Whitehand, S. M. (1984) The physical fabric of town centres: the agents of change, Transactions of the Institute of British Geographers, 9(2), pp. 231-247.

Zahariadis, N. (2003) Ambiguity and Choice in Public Policy: Political Decision Making in modern democracies (Washington DC: Georgetown University Press). 
Table 1. Cardiff Council documents used in the study

\begin{tabular}{|c|c|}
\hline Date & Name of Document \\
\hline $10^{\text {th }}$, Jan. 1975 & City Planning Officer's Report to Planning and Development Committee \\
\hline $2^{\text {nd }}$, May. 1978 & City Planning Officer's Report to Planning and Development Committee \\
\hline $11^{\text {th }}$, Feb. 1983 & City Planning Officer's Report to Planning and Development Committee \\
\hline $7^{\text {th }}$, Dec. 1984 & $\begin{array}{l}\text { City Planning and Development Officer's Report to Planning and Development } \\
\text { Committee }\end{array}$ \\
\hline $10^{\text {th }}$, May, 1988 & $\begin{array}{l}\text { City Planning and Development Officer's Report to Planning and Development } \\
\text { Committee }\end{array}$ \\
\hline $30^{\text {th }}$, Jun. 1988 & $\begin{array}{l}\text { City Planning and Development Officer's Report to Planning and Development } \\
\text { Committee }\end{array}$ \\
\hline $11^{\text {th }}$, Oct. 1988 & $\begin{array}{l}\text { City Planning and Development Officer's Report to Planning and Development } \\
\text { Committee }\end{array}$ \\
\hline Jan. 1992 & A Conservation Strategy \\
\hline $27^{\text {th }}$, Feb. 1992 & $\begin{array}{l}\text { Central Area Conservation Area Boundaries Review to Planning and } \\
\text { Development Committee }\end{array}$ \\
\hline Jan. 1993 & Churchill Way Conservation Area Planning Brief \\
\hline Sep. 1997 & $\begin{array}{l}\text { City and County of Cardiff Conservation Area Strategy approved by Planning } \\
\text { Committee }\end{array}$ \\
\hline $21^{\text {st }}$, July. 2004 & $\begin{array}{l}\text { Planning Committee's report of the check to the council on the appointment of } \\
\text { Conservation Groups }\end{array}$ \\
\hline $11^{\text {th }}$, April. 2006 & $\begin{array}{l}\text { Corporate Director's Report to the Executive Business Meeting on St. Mary } \\
\text { Street Conservation Area Appraisal }\end{array}$ \\
\hline & Corporate Director's Report to the Executive Business Meeting on Cathays \\
\hline $1^{\text {st }}$, April. 2009 & $\begin{array}{l}\text { Park, Charles Street, Churchill Way, Queen Street and Windsor Place } \\
\text { Conservation Area Appraisals }\end{array}$ \\
\hline $14^{\text {th }}$, July. 2010 & $\begin{array}{l}\text { Planning Committee's report of the check to the council on the appointment of } \\
\text { Conservation Groups, 14th July. }\end{array}$ \\
\hline $14^{\text {th }}$, July. 2010 & $\begin{array}{l}\text { Report on Appointment of Conservation Groups from the Clerk to the Council } \\
\text { and Planning Committee }\end{array}$ \\
\hline $13^{\text {th }}$, July. 2011 & $\begin{array}{l}\text { The Chief Officer Legal \& Democratic Services Report on Appointment of } \\
\text { Conservation Groups to Cardiff Council and Planning Committee }\end{array}$ \\
\hline
\end{tabular}

Table 2. Agents involved in the 1984 extension of Central Area Conservation Area No. 1

\begin{tabular}{llll}
\hline GOVERNMENT & PUBLIC & ACTIONS & RESULT \\
\hline
\end{tabular}




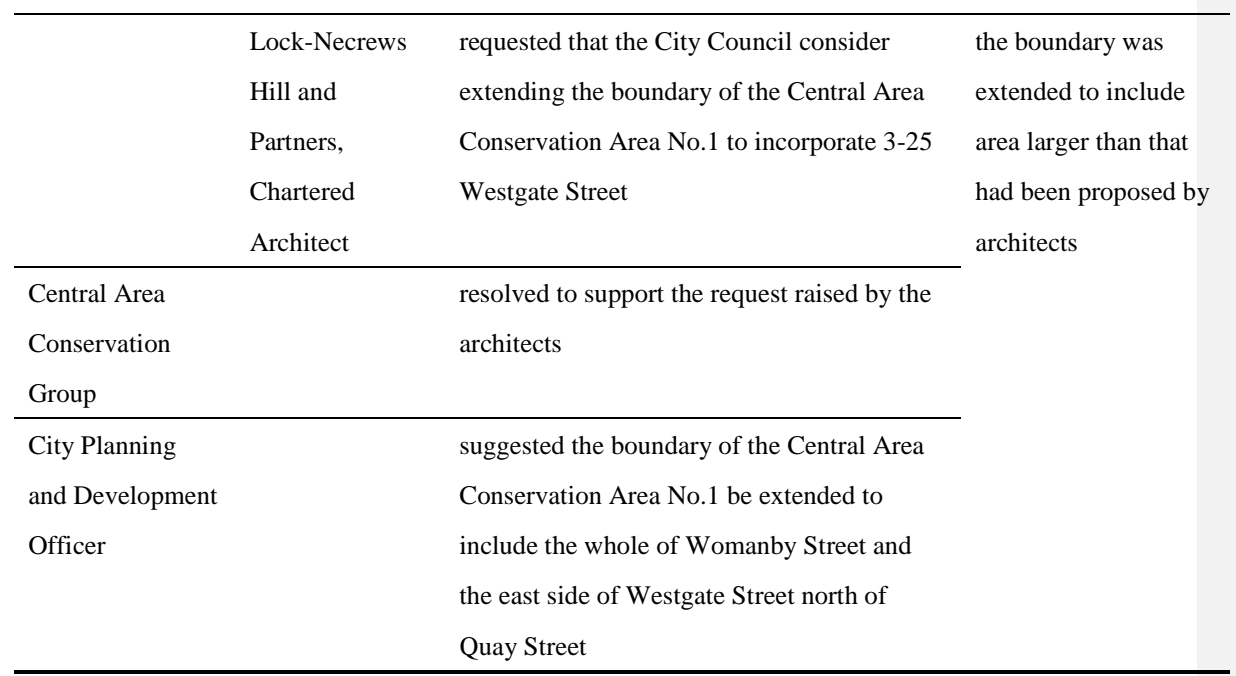

Table 3. The list of non-governmental agents in Cardiff Central Area conservation group in 2004.

\begin{tabular}{|c|c|}
\hline Non-governmental agents & Representatives \\
\hline Victorian Society & $\begin{array}{c}\text { Mr. M. Hockaday } \\
\text { Mr. J. Hilling }\end{array}$ \\
\hline Society of Architects in Wales & $\begin{array}{c}\text { Mr. L. Williams } \\
\text { Mr. S. Evans }\end{array}$ \\
\hline Cardiff Civic Society & Ms. L. Mahoney \\
\hline Cardiff Bay Business Forum & one vacancy \\
\hline Royal Town Planning Institute South Wales Branch & Mr. A. Parker \\
\hline Royal Institute of Chartered Surveyors South Wales Branch & Mr. S. Warder \\
\hline Cardiff University, Department of City \& Regional Planning & Mr. P. Barber \\
\hline Ecclesiastical Representative & Dr. S. Romaya \\
\hline Community Constable & Father K. Kimber \\
\hline Council for British Archaeology Historic Building Section & PC A. Withers \\
\hline Welsh School of Architecture & H. Conway \\
\hline
\end{tabular}




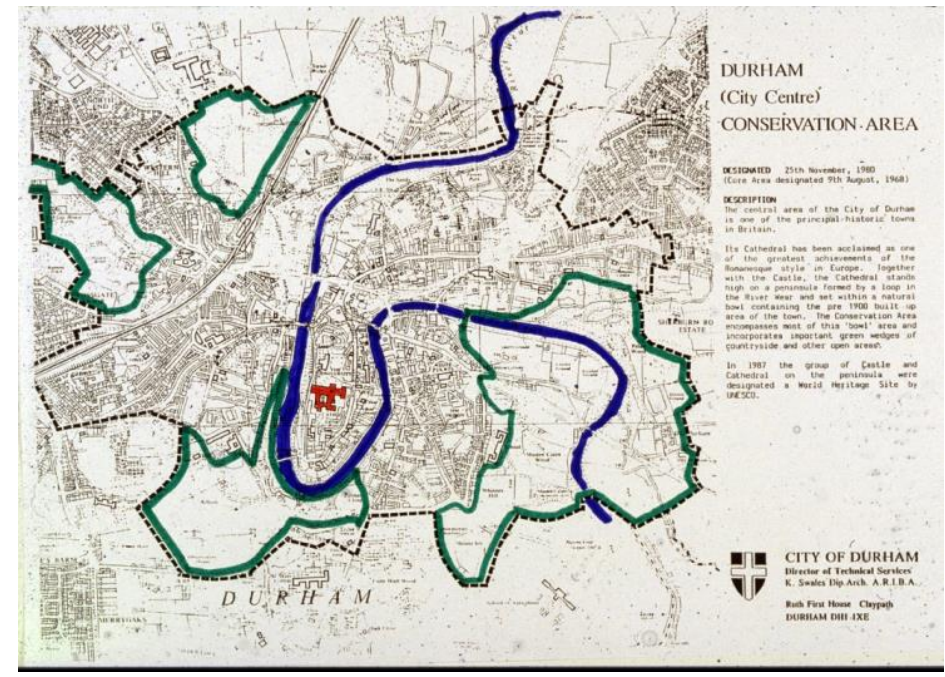

Figure 1. Durham city conservation area in 1980. The bold outlines identify the 'green wedges'. Map from Durham City Council, annotated by Peter J. Larkham. 


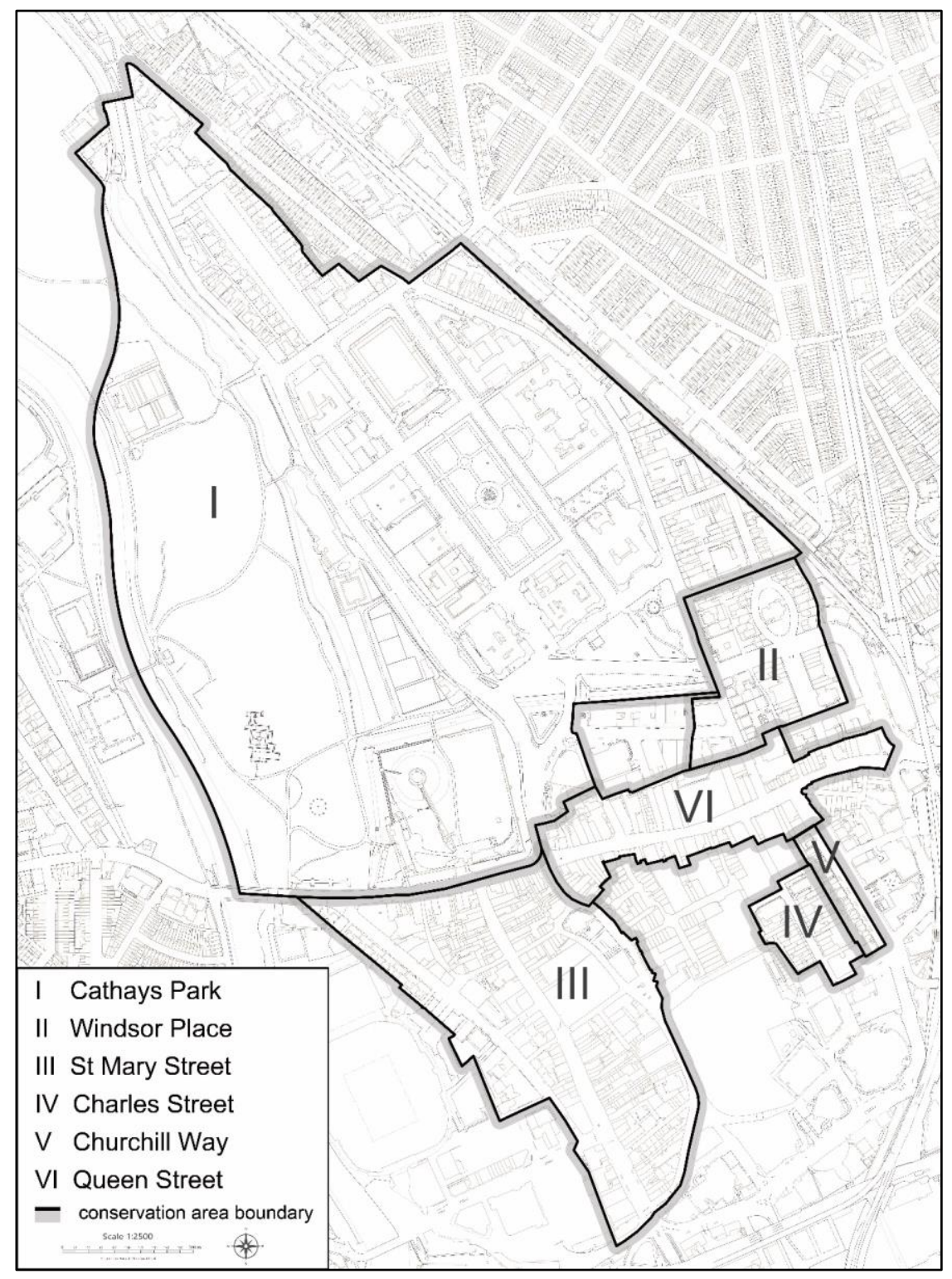

Figure 2. The six city-centre conservation areas, 2019. Source: Cardiff Council (based on Ordnance Survey/digimap: Crown copyright and database rights 2019 Ordnance Survey). 


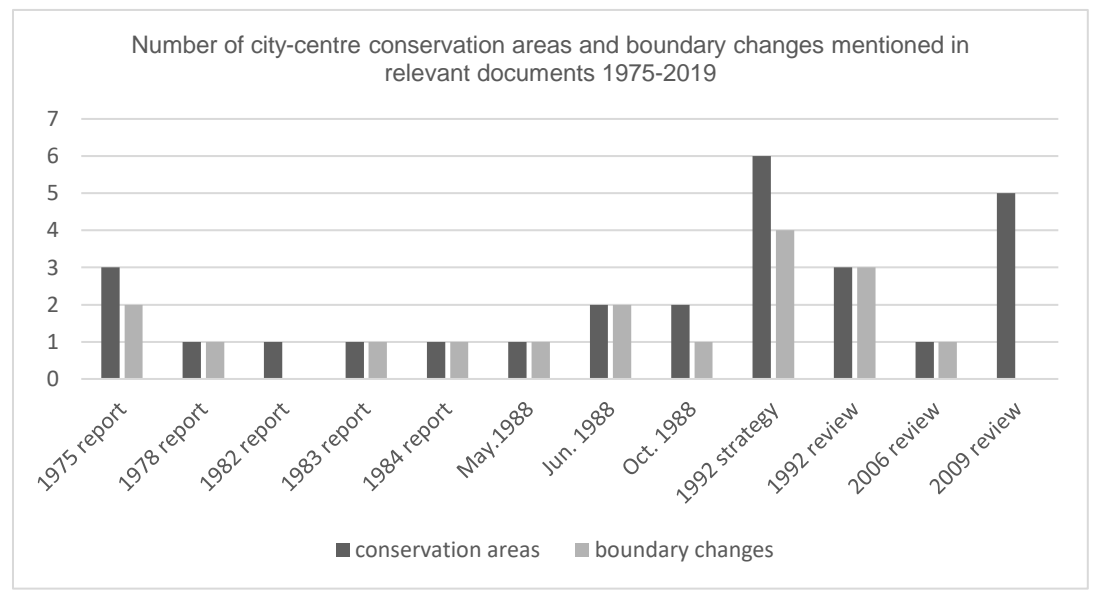

Figure 3. Numbers of conservation areas and boundary changes, as identified in official City Council documentation, 1975-2019. The 1997 conservation strategy and 1993 planning brief gave no information about agent participation or boundary change. 


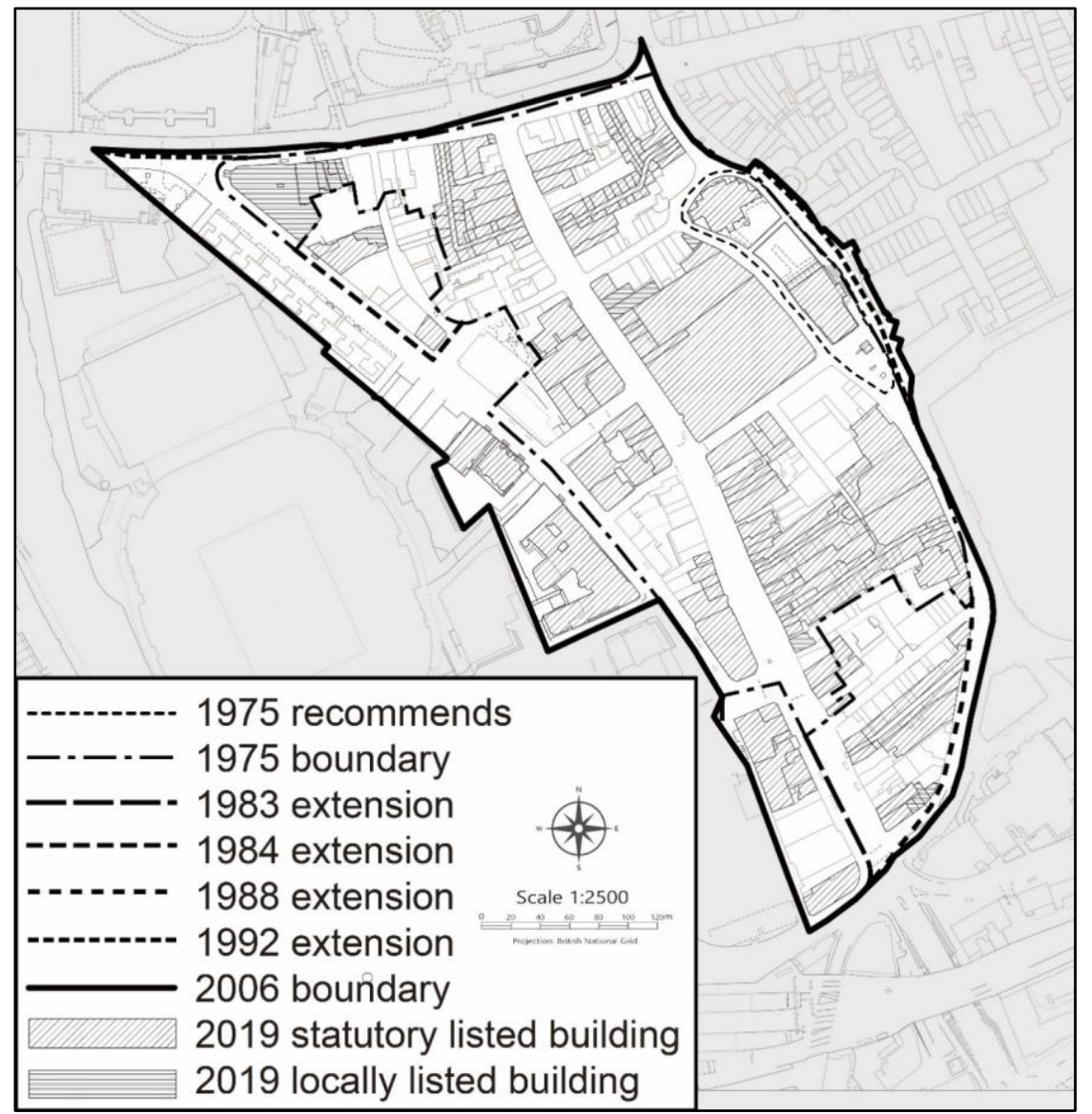

Figure 4. The boundaries of the St Mary Street Conservation Area. Source: Cardiff Council (based on Ordnance Survey/digimap: Crown copyright and database rights 2019 Ordnance Survey) 


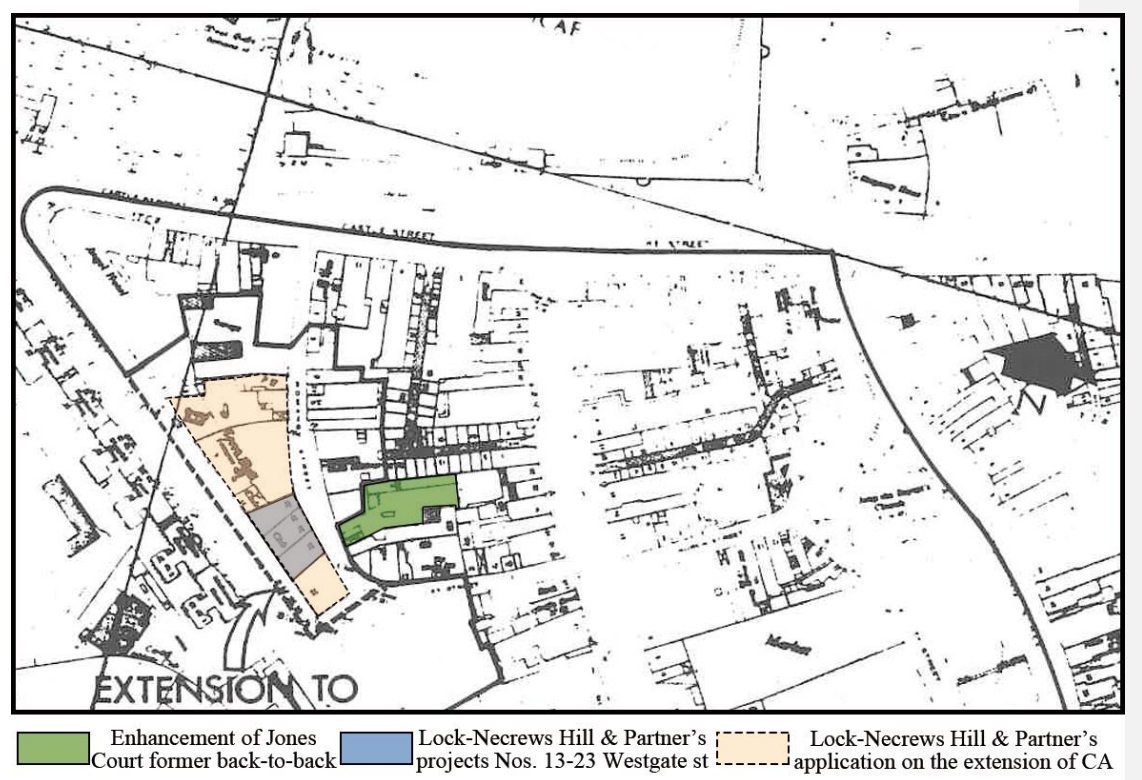

Figure 5. The change to the north boundary of St Mary Street conservation area (Central Area Conservation Area No.1) in 1984. Based on map in Cardiff City Council, 1984. 


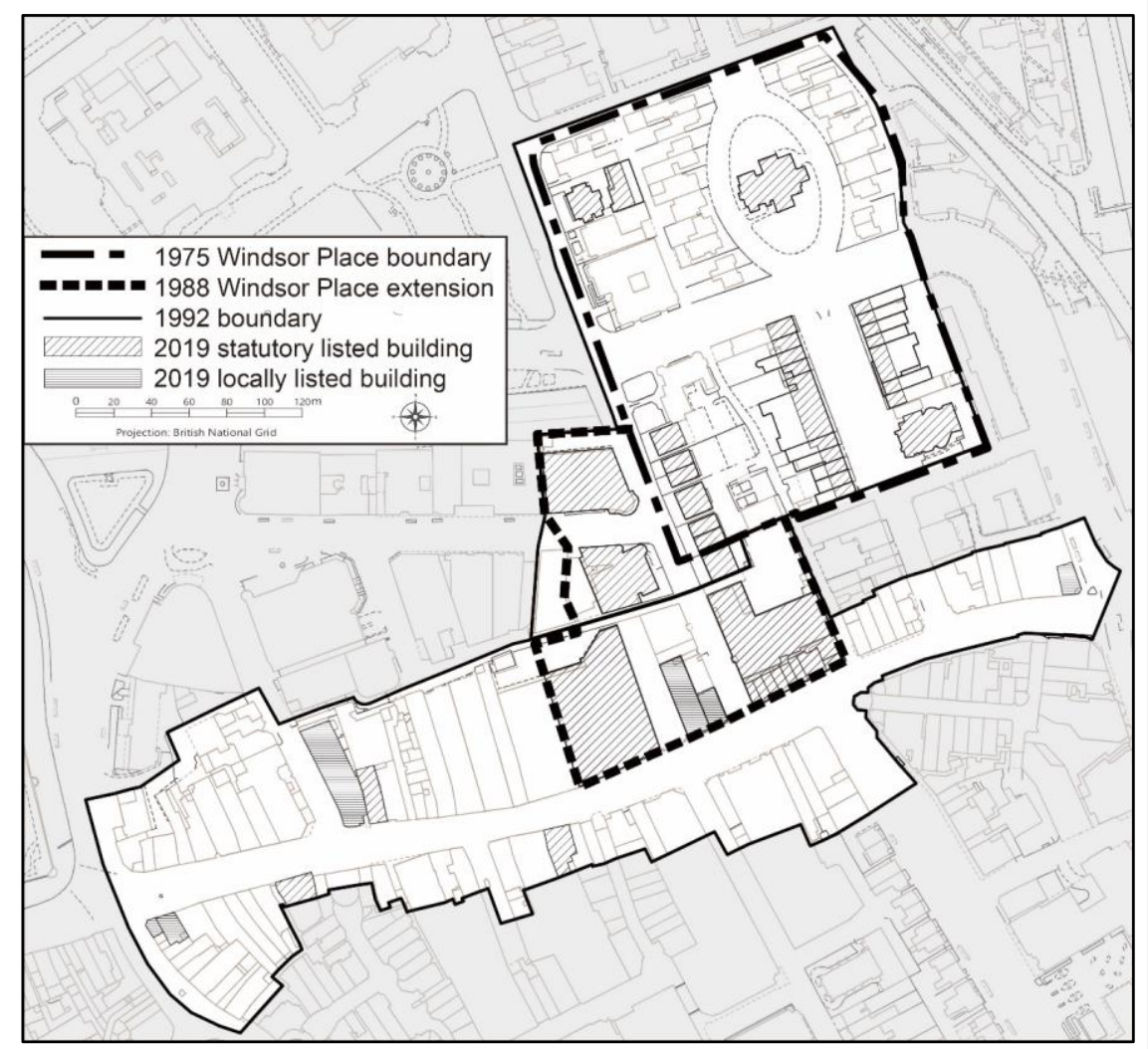

Figure 6. The boundary changes on Windsor Place and Queen Street. Source: Cardiff Council (based on Ordnance Survey/digimap: Crown copyright and database rights 2019 Ordnance Survey) 


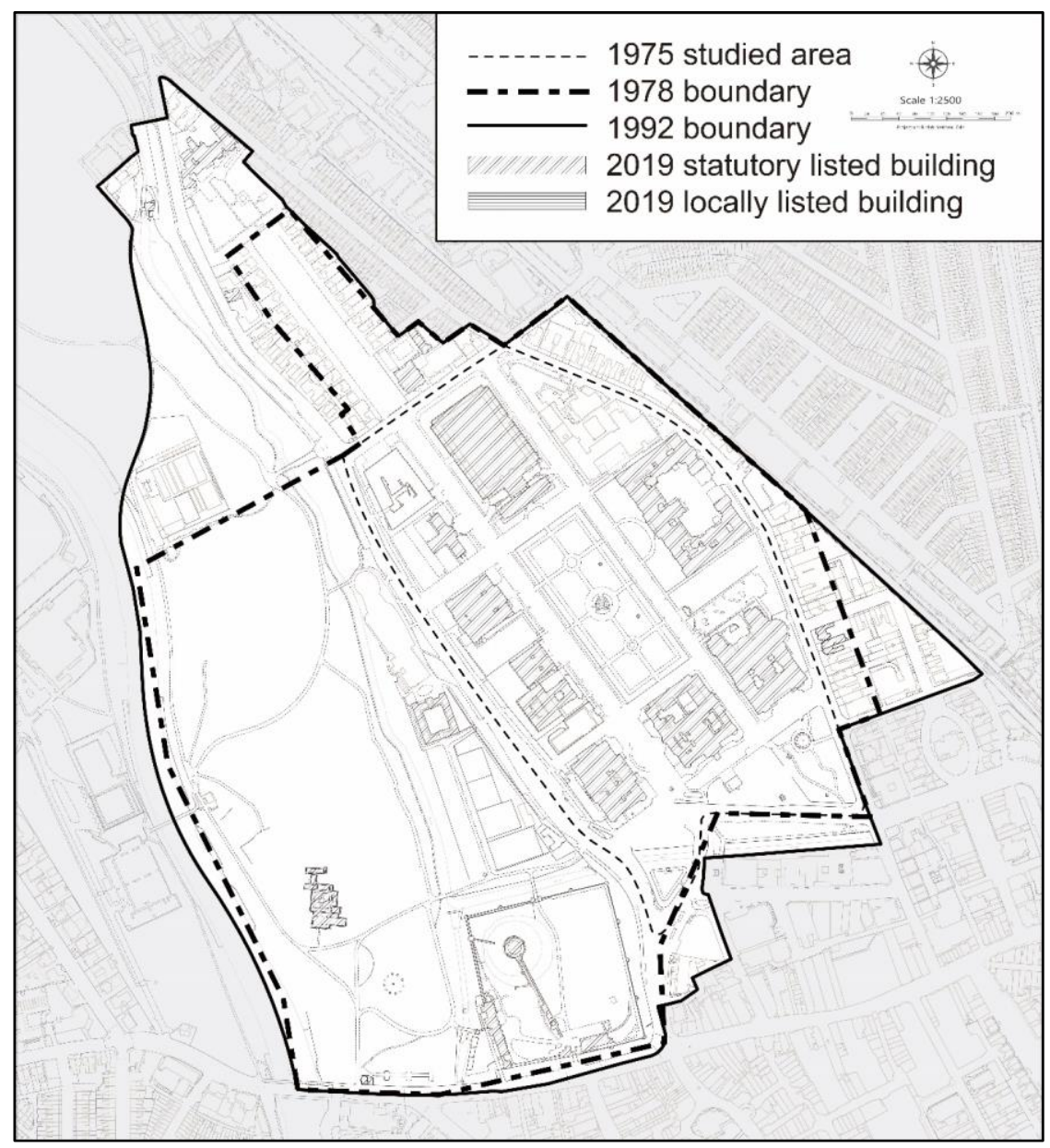

Figure 7. Boundary changes on Cathays Park Conservation Area. Source: Cardiff Council (based on Ordnance Survey/digimap: Crown copyright and database rights 2019 Ordnance Survey) 


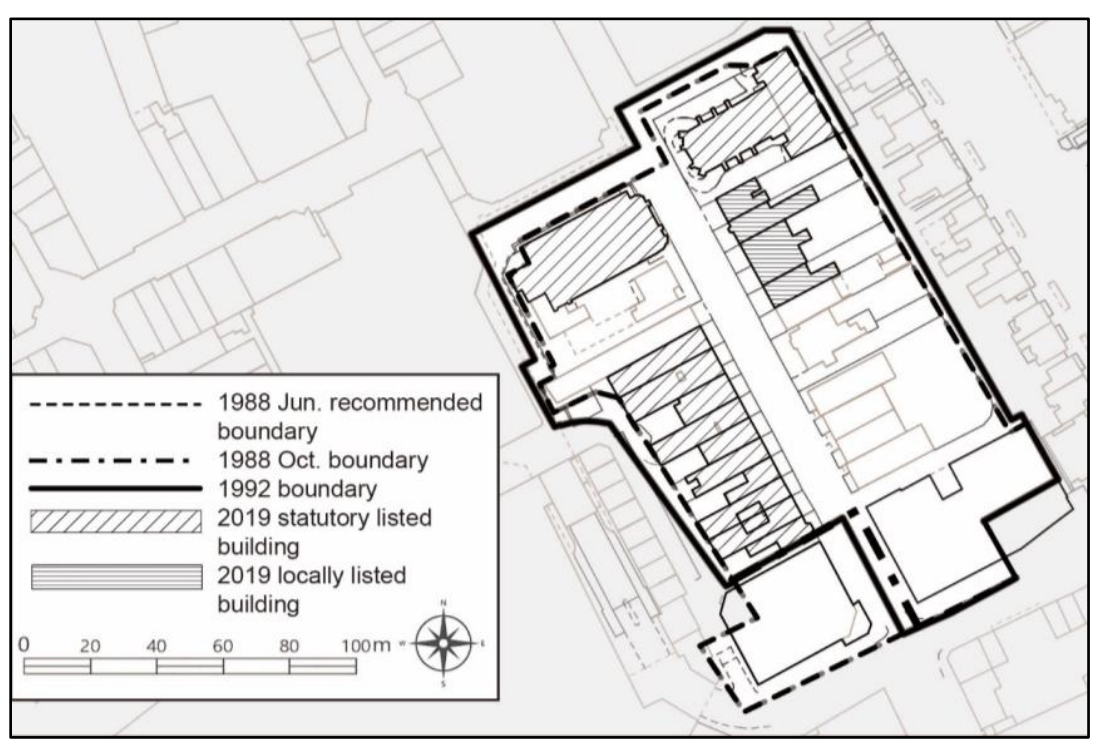

Figure 8. Changing boundary of Charles Street Conservation Area. Source: Cardiff Council (based on Ordnance

Survey/digimap: Crown copyright and database rights 2019 Ordnance Survey)

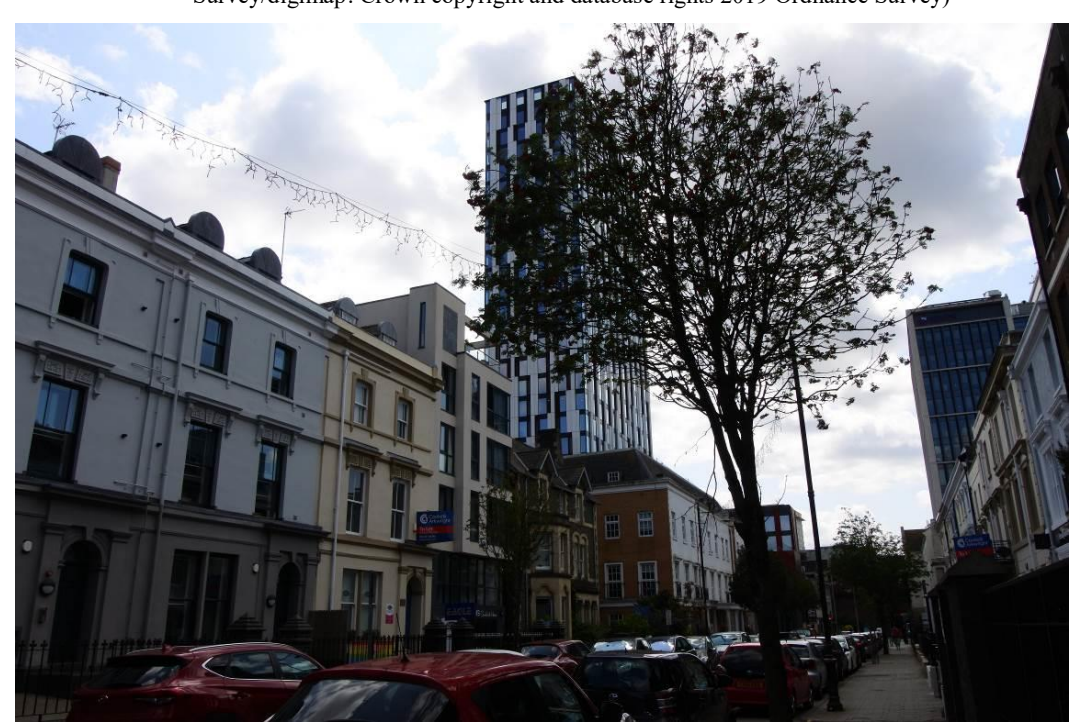

Figure 9. Bridge Street Exchange (in distance) and the Victorian terrace in Charles Street conservation area. Photograph taken by Luchuan Deng. 


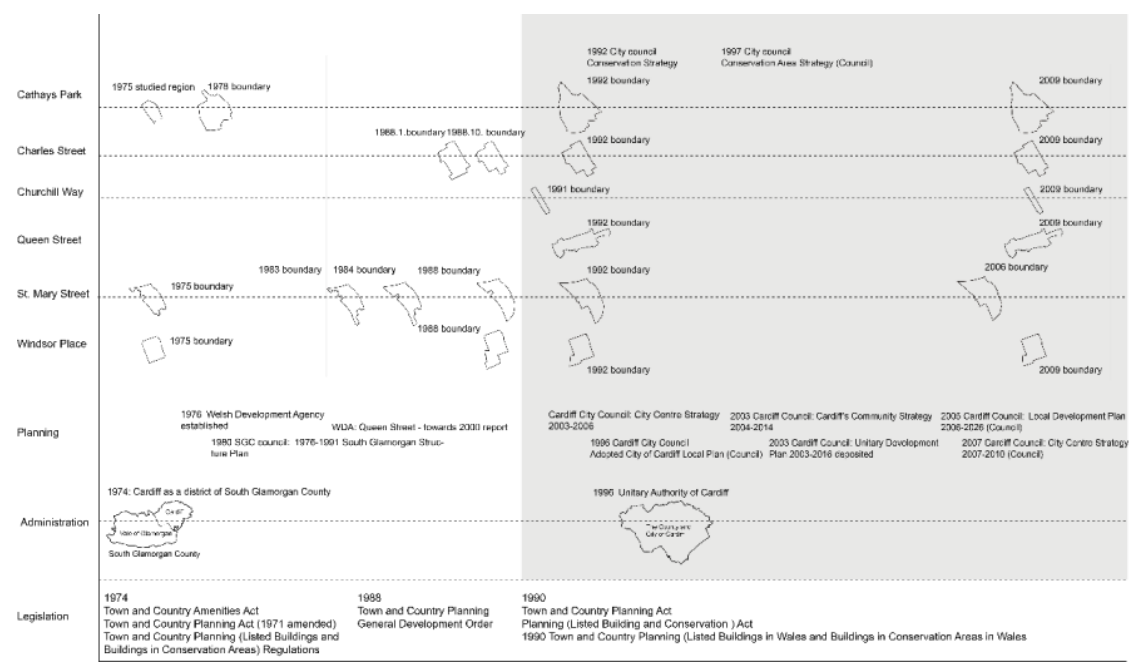

Figure 10. The process and background of boundary change in Cardiff's city-centre conservation areas.

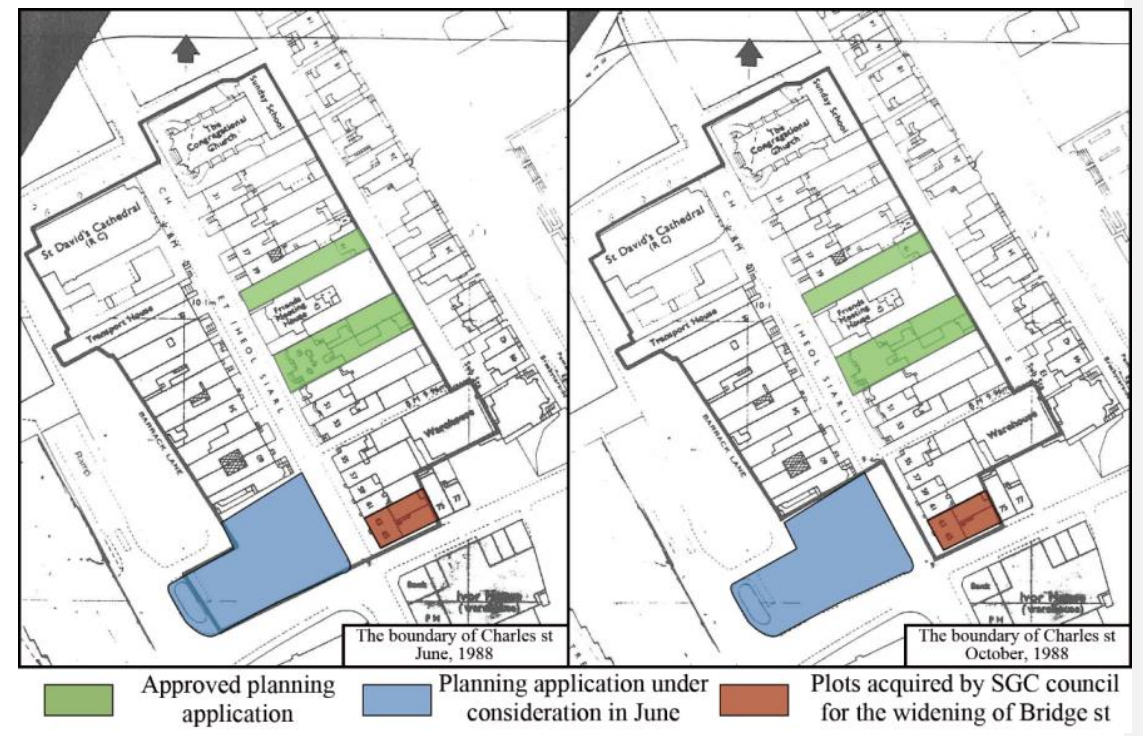

Figure 11. Charles Street conservation area before and after the two designations in 1988. Based on maps in Cardiff City Council, 1988b. 


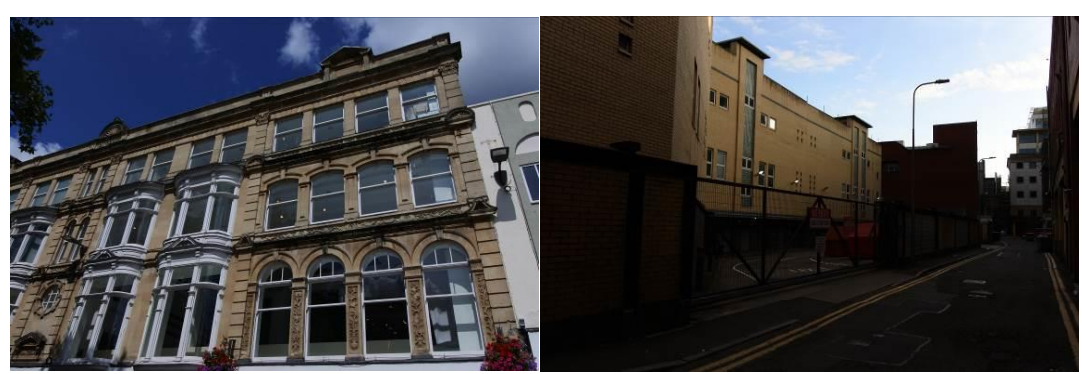

Figure 12. Façadism on Queen street. Left shows the façade and right shows the back of one Listed Building. Photograph taken by Luchuan Deng.

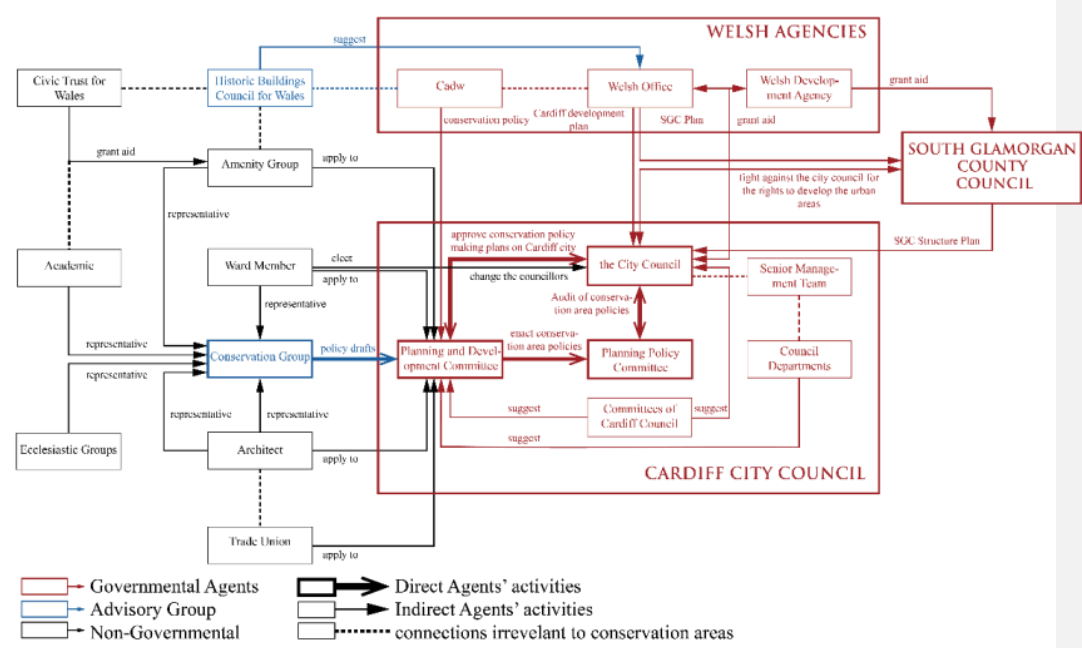

Figure 13. Decision-making framework for conservation areas in Cardiff city centre 1975-1999 (1984-1996 strictly: Cadw was not founded until 1984). 


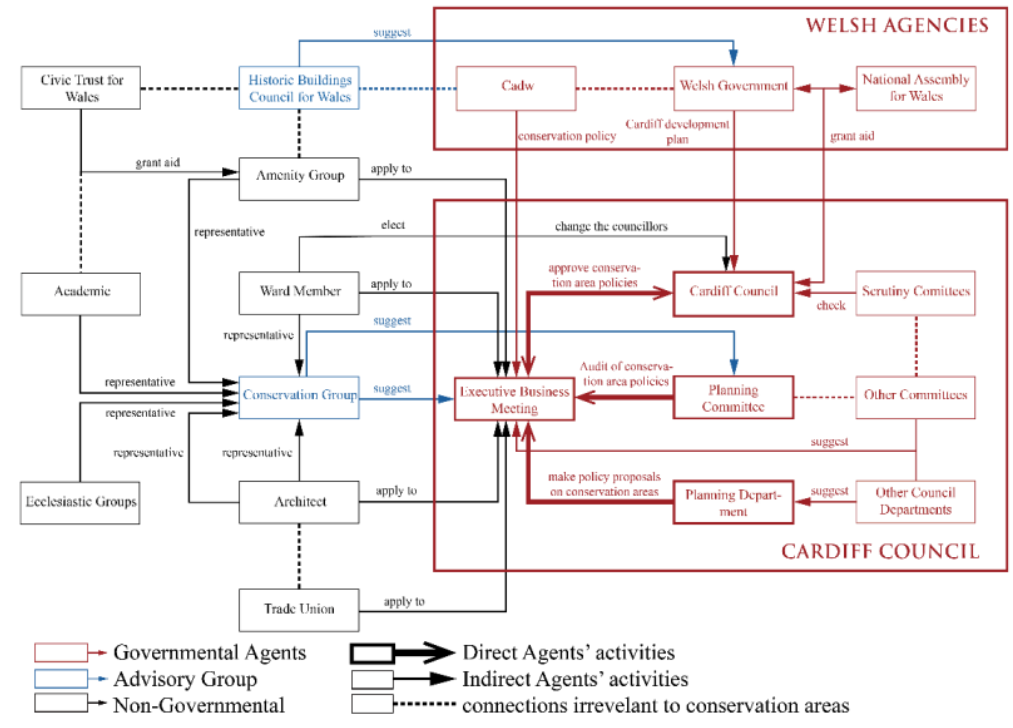

Figure 14. Decision-making framework for conservation areas in Cardiff city centre 1999-2012 (2006-2012 strictly WDA was abolished in 2006 so in order not to include it into the framework the time period has to be adjusted). 


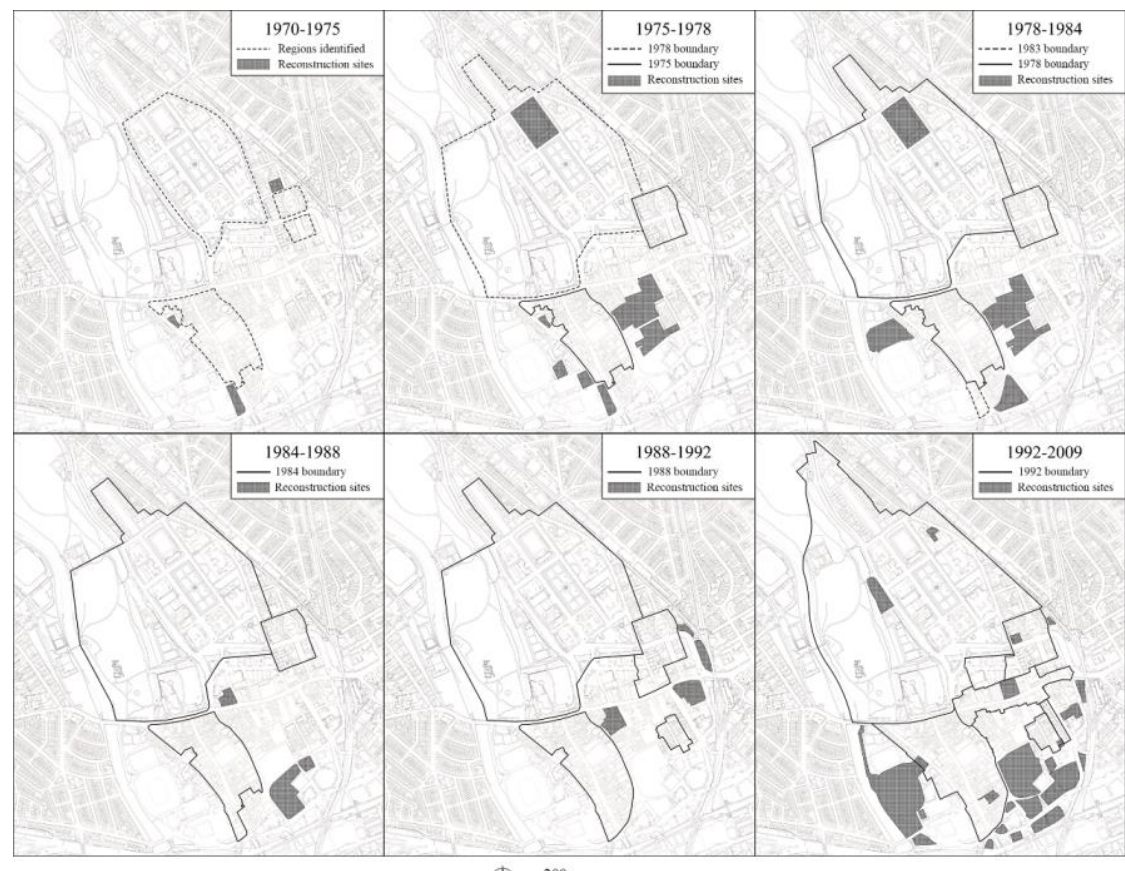

(200m

Figure 15. The changing boundaries of conservation areas and reconstruction sites in Cardiff city centre 1975-2009. Governance of Cardiff city centre Conservation Areas (CAs) 1975-1999 Governance of Cardiff city centre Conservation Areas (CAs) 1999-2012
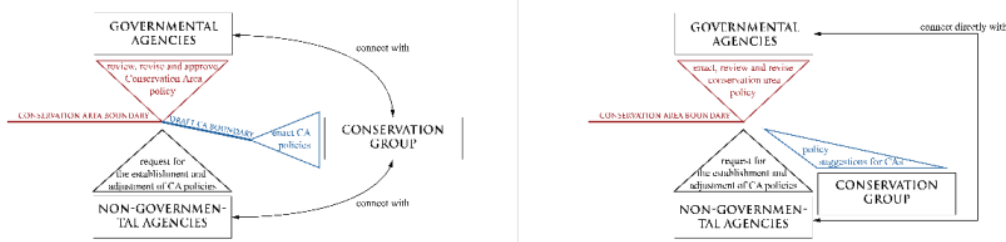

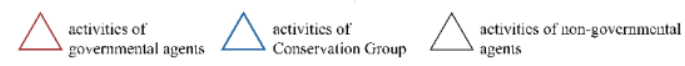

Figure 16. The relationship between different types of agents in the governance of Cardiff city centre conservation areas before and after 1999 Cardiff Council reform. 